\title{
Televizyon Ekranıyla Melezleşen Çocuk Oyunları
}

\section{Zeynep Gültekin Akçay}

\author{
Dr. Öğretim Üyesi \\ Cumhuriyet Üniversitesi Illetişim Fakültesi \\ Radyo Televizyon ve Sinema Bölümü \\ zga@cumhuriyet.edu.tr \\ orcid: 0000-0003-3050-3090
}

\section{Abstract}

\section{Child games hybridized with the television screen}

The study addresses the relationship between child plays and television. Starting from the point/ based upon the arguments that child games/ kids plays are hybridized with the television screen, the study aims to put forward the transformation of self-initiated kids plays which were used to re-enact the adult world once upon a time. The study is designed within a qualitative approach. In the study, the answers are sought for the questions such as "What is the relationship between the child plays and the television?", "Are there any traces from the television shows in the child plays?", and so on. In this context, some field studies were carried out in nine state kindergardens located in the center of Sivas during the spring semester of the 2015-2016 academic year. As a result of the study, it is observed that children now, produce their games from some popular television stories and characters. Because of that it is possible to say that the play is hybridized.

Key Words: Child games, Television, Hybridized Child Games, Cartoons 


\section{Résumé}

\section{Les jeux d'enfant hybridés avec l'écran télévisés}

Cette étude traite la relation entre les jeux d'enfant et la télévision. L'objectif de cette étude de constater la transformation des jeux d'enfant en s'appuyant sur la thèse selon laquelle les jeux d'enfant se sont hybridés avec la médiation télévisuelle. Cette étude utilise une méthode qualitative. On a cherché à répondre aux deux questions suivantes: Quelles sont les relations entre les jeux d'enfant et la télévision ? Y a-t-il des traces des narrations télévisées dans les jeux d'enfant? La recherche a été conduite durant le second semestre de l'année scolaire 2015-2016 dans neuf écoles maternelles publiques situées dans la province de Sivas. En conclusion, on a constaté que les enfants ont créé des jeux en étant affecté des personnalités et des histoires populaires à la télévision. II est donc possible de mentionner que le jeu est aussi en train de s'hybrider.

Mots-Clés : Jeu d'enfant, Télévision, Jeu d'Enfants Hybridé, Bandes Dessinées.

Öz

Çalışma, çocuk oyunları ve televizyon ilişkisini ele almaktadır. Çocuk oyunlarının televizyon ekranıyla melezleştiği savından hareket ederek, bir zamanlar yetişkin dünyasını canlandıran kendi kendine başlayan çocuk oyunlarının nasıl dönüştügünü ortaya koymak çalışmanın amacını oluşturmaktadır. Çalışma nitel yaklaşımla inşa edilmiştir. Çalışmada, çocuk oyunları ve televizyon ilişkisi nedir, çocuk oyunlarında televizyon anlatılarından izler var mıdır, gibi sorulara cevap aranmaktadır. Bu kapsamda 2015-2016 eğitim öğretim yılı bahar döneminde Sivas merkezde bulunan dokuz devlet anaokulunda saha araştırması yürütülmüştür. Çalışmanın sonucunda çocukların artık oyunlarını popüler televizyonun hikâyeleri ve karakterlerinden ürettiği görülmüştür. Bu sayede de oyunun melezleştiğinden bahsetmek mümkündür.

Anahtar Kelimeler: Televizyon ve Çocuk, Çocuk Oyunları, Çizgi Film ve Çocuk Oyunları 


\section{Giriş}

Meğer ne günler imiş! Cüz kesesi boynumda, sefertası elimde tin tin mektep. Cüz torbası belimde, meşin top cebimde, uçar gibi cami avlusu. Ta tepede kalmış bir avuç çitlembik için dört, beş metre yüksekliğe tırmanış (Ahmet Rasim). Keçiören Bağevi'nin büyük bahçesinde açık havada dolaşır, ağacından vişne, kiraz, dut yerdik. Bahçede ip atlar, sek sek oynardık. Bisiklete binmek, top oynamak, ağaçlara çıkmak, ağaçların altında evcilik oynamakla günümüz geçerdi. Körebe, köşe kapmaca hayatımızın bir parçasıydı (Suna Kıraç). Komşu kızlarıyla doyamadığımı evcilik oyunları kurduk evin önündeki kaldırımda. Bahçede erkek çocuklarla çığılk çığlığa dokuz kiremit oynadık, ağaçlara tırmandık, kavgalar ettik (Inci Aral). Senelerce dinlediğimiz ve hayatımıza televizyondan çok daha fazla renk katan radyolara nankörce sırt çevirdik. Oysa altmışlı yıllarda Ankara'da cumartesi akşamları sokakta arkadaşlarımızla oynarken bile gözümüz saatte olur, beş dedi mi radyoda 'Çocuk Saati'ni dinlemeye evlerimize koşardık. 'Çocuk Saati' bitince tekrar fırlar, dinlediğimiz piyes üzerine konuşur, bir süre sonra tekrar oyuna dalardık (Perihan Sarıöz) (aktaran Onur, 2007, s. 166, 170, 318, 329).

Oyunla ilgili bu anlatılanlar çok eski yıllar için geçerli değildir. Bundan elli sene öncesinde televizyonun henüz yaygınlaşmadığı zamanların çocuk oyunlarıdır. Tarih boyunca başkalarıyla ve kendi yarattığı oyuncakla oynamak anlamına gelen oyunun, zaman içinde anlamı dönüşmüştür. Oyun artık, insanın, hayatın gerçeklerini öğrenmesi, anlamlandırması ve uyum sağlaması için çocukluk döneminin sosyalleşme faaliyeti haline gelmiştir. Oyun kelimesinin anlamının dönüşümüne neden olan etkenlerden biri de televizyondur. 1970'li yıllarla birlikte hayatımıza giren televizyon giderek yaşamın her alanına yayılmış ve hatta çocukların saatlerini bile talep eder hale gelmiştir. Çocukların boş zaman kültürüne yapılan bu müdahale kamusal ve akademik çevrelerce 'yer değiştirme etkisi' (Neuman, 1988) kavramıyla ilişkilendirilmiş, televizyon izlemek, kitap okumak, ev ödevi yapmak, parkta oyun oynamak gibi önemli eylemlerin yerine mi geçmiştir sorusu ile birlikte tartışılır olmuştur. Günümüzde televizyon, çocukların yaşamının bir parçası olarak varlığını sürdürmektedir. Televizyon, çocukların ev dışındaki zamanlarının planlanmasında ve zamanlarının ayarlamasında belirgin bir değişim yaratmıştır. Çocuklar, arkadaşlarıyla oynamak yerine televizyon izlemeyi tercih etmiştir (Lemish, 2007, s. 96-97).

Televizyonla çok fazla zaman geçirmeye başlayan çocuğun hayatındaki pek çok unsur (ev ödevi yapmak, kitap okumak, yemek yemek, ailesi ve arkadaşlarıyla birlikte zaman geçirmek) gibi oyun oynamak da bu durumdan etkilenmeye başlamıştır. Televizyon, çocuk oyunları için zengin bir kaynak haline gelmiş aynı zamanda onların dönüşümüne de neden olmaya başlamıştır (Marsh ve Bishop, 2014, s. 67). Buradan hareketle televizyon ve çocuk oyunları ilişkisi çalışmanın konusunu oluşturmaktadır. Çalışmada Marsh ve Bishop'ın (2014, s. 17) televizyona karşı çocuk oyunlarının bir direnci olduğu düşüncesinden yola çıkarak, oyunların televizyon dolayımıyla melezleştiği, çocukların artık oyunlarını popüler televizyonun hikâyeleri ve karakterlerinden ürettiği savunulmaktadır. Bu sav doğrultusunda, çocuk oyunları ve televizyon ilişkisi nedir, çocuk oyunlarında televizyon anlatılarından iz var mıdır gibi sorulara cevap aranmaktadır. Araştırma 2015-2016 eğitim öğretim 
yılı bahar döneminde Sivas merkezde bulunan dokuz devlet anaokulunda yürütülmüştür. Araştırmanın çalışma grubunu paralel oyun dönemini bitirmiş beş yaş grubu sınıflarda öğrenim görmekte olan toplam 351 öğrenci oluşturmaktadır. Televizyon dolayımıyla oyunların melezleşmesinin anlaşılabilmesi için veri toplama tekniği olarak gözlem kullanılmıştır. Çocuklar, Milli Eğitim Bakanlığı müfredatında bulunan 'serbest oyun' saati sırasında kendi sınıflarında gözlemlenmiştir.

Televizyonun yaşantımıza girmesinden sonra televizyon ve çocuk üzerine çalışmalar iki koldan ilerlemiştir. İlki güçlü etkilerin tartışmaları ışığında, çocuğun tek yönlü televizyon etkisi altında olduğunu ortaya koyan çalışmalardır. Özellikle 1930'lardan 1960'lara kadar uzanan dönemde kitle iletişim araçlarının izleyiciler üzerinde sınırsız etkisinden bahseden çalışmalar medyayı çocuk karşısında güçlü kabul etmiştir. Güçlü medya- pasif çocuk tartışmalarında, televizyon, çocuk karşısında sınırsız bir egemen olarak görülmektedir. Çocuk hem bilişsel kapasitesinde sınırlııklar hem de toplumsal yaşantılar içerisinde deneyim ve seçme şansına sahip olabilme bilgisinden yoksun oluşu nedeniyle televizyon tarafından yönlendirilmektedir. Bu yönün niteliği ise genellikle olumsuz olarak ele alınmaktadır. Pasif çocuk tartışmalarına göre, televizyon bir uyuşturucu gibi çocuklar üzerinde bağımlıık yaratır ve yaşamlarının her alanında belirleyici role sahiptir (Timisi, 2011, s. 22-26). Televizyon ve çocuk üzerine yapılan tartışmaların diğeri ise, çocukların televizyon karşısında pasif ve içeriklerin işaretlendiği boş levha' (tabula rasa) olmadıklarını ileri süren yaklaşımlardır. Buna göre çocuklar, aktif televizyon tüketicileridir. Hangi aracı ve içeriği seçeceklerini bildikleri gibi bunlara dikkat etme, anlam çıkarma, mesajları anlama ve eleştirme ve hatta hatırlama gibi seçenekleri kullanıllar (Lemish, 2007, s. 3).

Çocukların, medya karşısında pasif olmadıklarını ileri süren tartışmalardan hareketle çocukların oyun kültürleri ile medya metinleri arasında ilişki olduğunu ortaya koyan, İngiliz çocuk kültürü araştırmaları için önemli isim olan lona ve Peter Opie'lerin (aktaran, Marsh ve Bishop, 2014, s. 28) 1960'lardan itibaren yaptıkları pek çok çalışmada çocuk oyunlarının medya içeriklerinden etkilendiği ve yararlandığı öne sürülmüştür. Onlara göre, çocuk oyunlarının temel kaynaklarından biri medyadır. Medya kaynaklarını ise reklam cıngılları, haber metinleri, popüler şarkı ve danslar, yetenek şovları, yarışmalar ve diziler oluşturmaktadır. 1982'de James ve Mc Cain'in (aktaran. Marsh ve Bishop, 2014, s. 67) araştırmalarına göre ise okul öncesi çocuklar oyunlarında televizyondan yararlanırlar. Onlara göre çocuklar beş farklı oyun türünde: Temel motor oyunlarında, inşa oyunlarında, dil oyunlarında, dramatik oyun ve sosyal oyunlarda televizyonun etkisini yansıtırlar. 1991 yılında, Elizabeth Grugeon'un (2004) 4-11 yaş çocuklarıyla yaptığı çalışma, çocuk oyunlarının medya içeriklerinden doğrudan etkilendiğini ortaya koymaktadır. Bu çalışmaya göre, çocuklar televizyon metinlerine karşı pasif alıcı değillerdir, onları yaşamlarına dâhil ederler. Çocuklar televizyon metinlerini alımlayıp oyunlarına aktararak yaratıcı yeni anlatılar ortaya çıkarmaktadırlar. Arleen Dodds ve arkadaşlarının (1992), Savaş ve Barış: Oyuncaklar, Öğretmenler ve

1 "Tabula Rasa (boş levha) J. Locke'un bir levha olarak zihin metaforudur; çocuğu, sayfalar doldukça olgunluğa doğru ilerleyen yetersiz biçimde yazılmış bir kitap olarak görür" (Postman, 1995, s. 80). 
Çocuklar başlıklı çalışmasında televizyondan etkilenen çocuk oyunlarında yaratıcılıktan bahsedilemez tersine olumsuz, karamsar yapıda oyunlar ortaya çıktığı vurgulanmaktadır. Uzun zamandır medya ve çocuk ile ilgili araştırmalar yapan Maya Götz ve Dafna Lemish'e (2003) göre çocuk oyunlarının temeli medya metinlerinin anlatı yapılarının doğrudan uyarlamasıdır. Bu uyarlamalar sadece kurgusal metinlerden değil aynı zamanda belgesel ve bilim programlarından da kaynaklanmaktadır. 2006 yılında Bishop ve Curtis'in (aktaran, Marsh ve Bishop, 2014, s. 67) yaptıkları çalışmada ise çocukların televizyon ile ilişkisi üç farkı biçimde ortaya çıkmaktadır. Bunlardan ilki, kinayedir. Çocuklar, televizyon karakterlerinin, yıldızların, marka isimlerini kullanıllar, onların jest ve mimiklerini kopyalarlar ya da televizyondaki konuyu kullanıllar. Oyunlarında kullandıkları ikinci bir yol ise, birleştirme ve melezleştirmedir, geleneksel oyun ile televizyonda karakter ve konunun melezleştirilmesidir. Arka Sokaklar dizisinden etkilenerek hırsız veya polis pratiklerini oyunlarına aktarmak örnek olarak gösterilebilir. Sonuncu ise taklittir. Çocuklar hikaye veya karakteri taklit ederken çok yaratıcı şekilde özgün kahramanlar ve yenilikçi olay örgüleri geliştirirler. Televizyonun, oyun oynama süresini ve oranını azalttığını ortaya koyan çalışmaya göre çocuğun dikkati televizyon ile dağıtılmakta hatta yok edilmektedir (Schmidt vd, 2008). Coyne ve arkadaşları (2016), televizyonda yayınlanan Walt Disney prenseslerinin fanları ile üç sene boyunca etnografik çalışma yapmıştır. Bu çalışmaya göre kızlar oyunlarında sadece prenseslerin hikayesini kullanmaktadır. Bu durum, çocukların erken bir dönemde toplumsal cinsiyet algılarına etki etmektedir.

Çocukların, medya karşısında pasif olmadıklarını ileri süren tartışmalardan hareketle çocukların oyun kültürleri ile medya metinleri arasında ilişki olduğunu ortaya koyan bu çalışmalardan anlaşıldığı üzere Batı Bilim dünyasında çocuk oyunları ve medya ilişkisini ele alan çok sayıda araştırma söz konusudur. Türkiye'de ise çocuk oyunları üzerine Pertev Naili Boratav (1973), Bekir Onur $(2005,2007)$ gibi bilim insanlarının çalışmaları ile 1994'te kurulan Ankara Çocuk Kültürü Araştırma ve Uygulama Merkezi daha çok halkbilim ve eğitim alanında önemli katkılar sunmuştur. İletişim disiplininde ise çocuk ve televizyon ilişkisi iki açıdan ele alınmıştır. Televizyon ve çocuk ilişkisi, metin açısından, şiddet, tüketim kültürü, toplumsal cinsiyet gibi konularla ilişkilendirilerek incelenmiştir (Timisi, 2012; Tokgöz, 1982, Akçalı, 2014, Öcel, 2002). Diğer çalışmalar ise televizyonun çocuklar üzerindeki etkisi (Gönenç ve Gönenç, 2003, Aydoğan, 2014; Büyükbakkal, 2007) açııından çalışılmıştır. İki açıdan da araştırmaların sayısı fazla olmasına rağmen oyun kültürü ve televizyon ilişkisini ele alan çalışmaların sayısı çok azdır. Bununla birlikte Mustafa Yaşar ve Ipek Paksoy'un 2011 yılında okul öncesi beş yaş grubu çocuklarla yaptıkları araştırmada çocukların izledikleri çizgi filmlerdeki saldırgan içerikli görüntülerin, çocukların oyunlarına olumsuz etki ettiğini ortaya koymuşlardır. Ankara'da bir ilkokulun bahçesinde çocukları gözlemleyerek çocuk oyunları ve televizyon ilişkisini kültürel-ekolojik yaklaşımla açıklamaya çalışan araştırmada, oyunların televizyondan kısmen etkilendiğinden bahsetmektedir (Bağlı, 1999). Televizyon metinlerinin çocuk oyunlarına olumsuz etki ettiğinden bahseden Kemal İnal'ın (2014) çalışmasına göre "geleneksel çocuk oyunlarının naifliği yerini, endüstrileşen oyun ve oyuncağın araçsalcı mantığına" bırakmıştır. Sormaz ve Yüksel'de (2012) oyuncak ve oyunların endüstriyel bir yapıya kavuşmasında televiz- 
yonun yadsınamaz bir etkisi olduğundan bahsetmektedir. Bahsedilen bu dört çalışma televizyon ve çocuk oyunlarını tek yönüyle ele almaktırlar. Bu çalışma, bahsi geçen çalışmaların devamı niteliğinde kabul edilebileceği gibi televizyon ve oyun ilişkisini, televizyonda yayınlanan tüm programları ele almasıyla, mekan olarak anaokullarında yürütülmesiyle, beş aylık bir süreyi kapsamasıyla diğer çalışmalardan farklılaşmaktadır. Çalışma iletişim disiplininde televizyon ve çocuk araştırmalarına bir nebze de olsa katkı sağlama çabası içindedir.

\section{Çocuk ve Televizyon}

Çocuklar neden televizyon izlemektedir sorusuna Neil Postman (1995), şu yanıtı verir: Televizyon, biçimi anlamayı sağlayacak bir eğitim gerektirmez, zihin ve davranışlardan istemlerde bulunmaz ve izleyicisini ayrıma tabi tutmaz. Televizyonun evin bir parçası olması, hemen el altında olması, popüler olması, kolay, ucuz olması soruya verilen bir başka yanıttır. David Elkind'e (1995) göre, günden güne düzenlenen televizyon, çocuğu cezalandırmaz ödüllendirmez, sevmez, hırpalamaz ancak onun hislerine, eylemlerine yanıt verir. Çocuk bu ekranda gördüğü, duyduğu durumları kendi ilgi alanına geçirmekte ve onların bir bölümü doğrudan onun yaşam biçimini, varlığını etkilemektedir.

Bu durumda ev içinde sınırsız eğlence imkânı sunan televizyonun çocuklarla olan ilişkisine değinmek gerekmektedir. Televizyon ve çocuk ilişişini ele alan araştırmalar iki açıdan ilerlemiştir. İlki televizyonun çocuklar üzerindeki etkisini araştıran, onların olumsuz davranışlarına tek neden olarak televizyonun gösterildiği çalışmalardır. Bu çalışmalara göre insanlar, televizyon yaşamlarına girmeden önce ailece toplanıp zamanlarını sohbet ederek, farklı uğraşılarla ve paylaşımlarda bulunarak geçirmekteydiler. Televizyon, insanların yaşantılarına girdikten sonra bu paylaşımlar yavaş yavaş ortadan kalkmaya başlamıştır. Bu nedenle de çocuk için güçlü etki ve cazibeye sahip olan televizyon, gerçek aile etkileşimini yıkan hipnotik bir güce de neden olmuştur (Kline, 1993, s. 70). Bu çalışmalara göre televizyon duyguları uyuşturabilir, düş gücünü ya da esneklik yeteneğini kısıtlayabilir, başkalarını incitecek şekilde umursamazıık geliştirebilir, yıkıcı davranışları yüreklendirebilir, çocukları şiddete karşı duyarsız kılabilir, kalıplaşmış davranışlara süreklilik kazandırabilir, ahlaki değerlerin yozlaşmasına yol açabilir, yerel kültürü bastırabilir ve toplumsal kayıtsızığa katkıda bulunabilir. Bir taraftan ise çocuk ve televizyon ilişkisinde televizyonun olumlu yönlerinin de olduğunu belirten çalışmalar söz konusudur. Bu çalışmalara göre ise, televizyon çocukların hayatını zenginleştirir, sağlıksız davranışları değiştirebilir, çocukların düş gücünü ve yaratıclığını harekete geçirebilir, eğitim ve bilgilerini arttırabilir, çocukların topluma dahil olmalarını ve hoşgörü göstermelerini destekleyebilir, toplumsal boşlukları daraltabilir ve gelişmeyle sivil toplumu özendirebilir. Bu çalışmalar, çocukların medyayı etkin olarak kullandığını belirtmektedirler. Çocuklar, izledikleri içeriklere tepki göstermekte, içeriklere dair düşünmekte ve hatta kendi anlamlarını yaratmaktadırlar. Çocuklar televizyonda gördüklerini ve duyduklarını, sayısız eğilime, yeterlilik inancına, arzu ve deneyime dönüştürler (Lemish, 2007; Lemish ve Kolucki, 2013). Televizyon ve çocuk ilişkisi üzerine düşünürken şu göz 
önünde bulundurulmalıdır: televizyonun, ilettiği içerik, tüketilme ortamı ve koşulları, onlardan yararlanış biçimleri, çocukların yaşı ve diğer özelliklerine bağı olarak hem olumlu hem de olumsuz etki yaratabilir. Bu durumda televizyonun kendi içinde ve kendi başına iyi ya da kötü olması söz konusu değildir.

\section{Dönüşen Oyun Kültürü}

Tarih boyunca çocuk kültürü ile oyun kültürü paralellik göstermiştir. Çeşitli bakış açılarına göre oyununun kökeni, yaşam sevincinden kurtulmanın bir yolu, doğuştan gelen bir taklit yeteneği, insanın gevşeme ihtiyacını tatmin etmesi, hayatın ciddiyetine karşıık bir hazırlık dönemi, egemenlik kurma, yarışma ihtiyacı, zararlı eğilimlerden masum şekilde kurtulma yolu, gerçek hayatta gerçekleştirilmesi olanaksız arzuların kurmaca yolu ile yatıştııımasından kaynaklanmaktadır. Oyunun, oyun olmayan başka bir şey karşısında beliren ve bazı biyolojik beklentilere cevap verdiği varsayımlarından yola çıkan bu tanımlara Johan Huizinga (1995, s. 48) karşı çıkmaktadır. O'na göre oyun, "özgürce razı olunan, ama tamamen emredici kurallara uygun olarak belirli zaman ve mekan sınıları içinde gerçekleştirilen, bizatihi bir amaca sahip olan, bir gerilim ve sevinç duygusu ile 'alışılmış hayattan başka türlü olmak' bilincinin eşlik ettiği, iradi bir eylem veya faaliyettir". Huizinga'nın yapmış olduğu tanım bazı oyunlar için geçerli olmakla birlikte tüm oyunları kapsamamaktadır. Jean Piaget'e göre (2013), oyun, bilinen şemaları tekrarlayarak var olan becerileri güçlendirebilir; çocuğa benliğin sürekliliği duygusunu yani kendine güven ve egemenlik duygusu kazandırır. Oyunu bulanık bir kavram olarak tanımlayan ve oyunun idealleştirilmesini eleştiren bir tanıma göre oyun, "rüyaları, gündüz düşlerini, fanteziyi, imgelemi, yalnız oyunu, kurallı oyunları, sporları, festivalleri, karnavalları, televizyonu, video oyunlarını, sanal gerçekliği vb. içine alan değişken bir kavramlar ailesini içerir; bu kavramlar bir kültürden diğerine geçtikçe değişir" (Onur, 2005, s. 34).

Oyuna ilişkin birçok kuram ve tanım çocuk davranışlarının özelliklerinden çok, yetişkinlerin çocukların davranışlarını örgütleme ve denetleme isteğinden kaynaklandığını belirtmektedir. Oyun ile iş, çocuk ile yetişkin arasındaki kavramsal ayrımının sonucu olarak oyun, önceleri Pieter Bruegel'in² resmettiği gibi çocukların bir etkinliği olarak sayılmıştır. Yirminci yüzyılın ortalarından itibaren ise oyun ve is ayrımı giderek azalmıştır. Mouritsen' $e^{3}$ (1998) göre çocukların oyun-

2 Pieter Bruegel'in 1560 tarihli 'Çocuk Oyunları' başlıklı yapıtı (Kunsthistorisches Museum, Viyana), Batı sanatında çocuk ve oyun temasına ilişkin en önemli görsel örnektir. Yapıtta iki yüzden fazla çocuğu yaklaşık doksan kadar oyunu oynarken betimlediği resmini, Avrupa kültürünün yüzyıllara dayanan oyun kültürü ile belleğinin görsel bir tanıklığına dönüştürür (Yüzgüller Arsal, 2014, s. 137).

3 Postmodern çocukluğun içinde birden fazla çocuk kültürü olduğunu ileri süren Felemming Mouritsen'e (1998) göre, çocuk edebiyatı, drama, müzik gibi geleneksel araçlar ile televizyon programları, video, bilgisayar oyunları ve reklamlar gibi yetişkinler tarafından çocuklar için üretilmiş kültürdür. Bu kültürel üretimin en ez iki alt alttürü bulunmaktadır. Sanatsal ve eğitsel yönleri bulunan nitelik yönelimli kültür üretimi bunun ilkidir. Bu kültür üretiminin tam tersi olan Pazar yönelimli kültür üretimi ise ikincisidir. Alt kültürün üretiminde sınırlar çok akışkan olsa da işlevseldir. Bir başka üretilen çocuk kültürü ise farklı kültürel teknoloji ve medya ile birlikte çocuk ve ebeveynlerle üretilen kültürdür. Bu tip kültürel üretim türü toplum için yaşamsal ve çok köklü bir geleneğe sahiptir. Sınırları akışkan olan bu üretimin de iki alt türü vardır. Bunların ilki, özelleşmiş boş zaman etkinlikleridir ki buna tüm çocuklar katılırlar (spor ve müzik kursları gibi). İkincisi ise 
ları işe benzer bir nitelik kazanmış ve okul çalışması çocuklara oyun aracılığıyla sunulur olmuştur. Çocukların toplumsal dünyaya katılığı, yetişkinlerin de oyun oynadığı yani çocukların yaşamıyla yetişkinlerin yaşamının iç içe girdiği bu durum oyunun dönüșümü kavramıyla tanımlanmaktadır.

Çocukların oyunları çocuklara özgüdür, ama aynı zamanda oyun zamanları, nesneleri ve alanları yetişkinlerce belirlenir. Dolayısılla çocukların oyunları hala gözaltındadır; özellikle tehlikeli görünen oyunlar ve oyunun bitiş zamanı yetişkin denetimindedir. Öte yandan, ayrı bir dünya yaratmadaki dönüştürme süreci aracılığıla sosyal ve fiziksel çevre çocukların denetimi altına girer. Çocukların çevreyi etkin olarak değiştirebilmeleri sayesinde, toplumsal dünya üzerinde hem özerklik hem güç uygularlar. Aynı oyun dünyaları dönüştürme süreci aracılığılla yeni kimlikler -kovboy, prenses olmak gibi- edinirler. Kısacası oyun yetişkin dünyasından kavramsal olarak ayrı olsa da aslında yetişkin dünyası hakkındadır. Oyunun oluşumu güç, denetim ve kimlik konularıla yakından ilişkilidir. Oyun gerçekliği taklit etmez, onu simgesel bir deneyim süreci içinden kurar; bu süreç toplumsal gerçekliği yeniden üretebildiği gibi onu tersine de çevirebilir. Çocuklar gelecek kimliklerini şimdiki zamana dönüştürerek kendi geleceklerinin imgeleriyle oynarlar; çocuklar gelecek kimliklerini şimdiki toplumsal ilişkileri denetlemek ve tartışmak için kullanılırlar. Bu özellikler sadece fantezi oyunları ${ }^{4}$ için değil, kurallı oyunlar için de geçerlidir (Onur, 2005, s. 37).

Oyunun evcilleştirilmesi ile birlikte günümüz çocuklarının önceki nesillere göre edilgin yaşama yönlendirildiğine işaret eden David Elkind'e göre (2011) öğrenme, merak, imgeleme ve düş kurma için çocukların doğuştan getirdiği yatkınlık olan oyun, yaratılan yüksek teknolojili ticarileştirilmiş dünyada susturulmaktadır. Çocukların bir zamanlar üzerinde kendi kişisel efsanelerini yarattıkları oyuncaklar, şimdi edilgin tüketim alışkanlıklarının pek ötesine geçememektedir. Eskiden kendiliğinden başlayan sokak oyunlarının yerini örgütlü takım sporları ve melezleşmiş oyunlar almıştır. Televizyon anlatıları bir zamanlar yetişkin dünyasını canlandıran (ve taklit eden) kendi kendine başlayan oyunları değiştirmiştir.

Elbette televizyon geleneksel oyun oynama biçimini değiştirmiştir ancak oyun oynamanın kendisini ortadan kaldırmamıştır. Geleneksel çocuk oyunları, kendini topluluk içinde sınama, sorumluluk alma, yardımlaşma, paylaşma gibi toplumsallık içeren özelliklere sahiptiler. Günümüzde ise, çocukluğun ayrılmaz parçası olan düşsel dünya imgelemi, çocuk açısından boş zamanlarında kurgulanan, hayale dalınan bir dünya olmaktan çıkmakta, televizyon üzerinden yetişkinler tarafından kurgulanan düşselliğe kendini teslim etmektedir. Televizyon öncesinde oyunlar ya geleneksel olarak toplumsal aktarımdan ya arkadaşlar arası oyunlar kurmadan ya da çocuğun hayal gücünden kaynaklanmaktadır. Bugün bunların hala mevcut olduğu doğrudur, henüz ortadan kalkmamıştır ancak bunlar televizyon varsa yaşayabilmektedir. Okul ve arkadas cevresinin etkisi devam etmekle birlikte televizyon

çocukların kendi ürettikleri veya yetişkinlerle yaptıkları informel projelerdir (kendini dene, yazı ve medya atölyeleri gibi). Çocukların kendi ağları içinde ürettikleri anlatım yolları ise üçüncü bir çocuk kültür türüdür. Bu kültürün en yayın olanı oyun, masal, tekerleme, şaka gibi formlarla geleneksel çocuk folklorunu içerirken aynı zamanda zamansal, ritmik sesler, şarkılar, yürüyüşler, sesler gibi estetik formları da içerir.

4 Fantezi Oyun: Çocukların sözel açıklamalarla mekân ve hareketleri canlandırmalarıdır (Özdoğan, 2000, s. 122). 
oyun arkadaşı yerine geçmiştir. Televizyon modern yaşamın kaybolmaya yüz tutan toplumsallığının yerini almıştır. Mahallelerden evlere kapanan çocukların arkadaşı televizyondur. İzleme aracılığıyla zaman geçirilmektedir. Günümüz çocuk programları, çocukları içeriğin akışına davet etmektedir (Timisi, 2011).

\section{Yöntem}

Televizyonun çocuklar üzerindeki etkisini araştıran, onların olumsuz davranışlarına tek neden olarak televizyonun gösterildiği yalıtımcı ve indirgemeci 'etki' araştırmasından ziyade, araştırma, televizyonla dolayımlanan çocuk oyunlarının özgül yanlarını ortaya koymayı hedefleyen nitel yaklaşım çerçevesinde inşa edilirken, medya etnografisinin bakış açısından beslenmeye çalışmıştır. Etnografik yaklaşım televizyon incelemelerinde, gündelik yaşamda içeriğin tüketimi ve televizüel anlamın üretimi gibi konuların anlaşılmasına yardımcı olmaktadır. Bu tür araştırmaların küçük ölçekli olması kuşkusuz bunlardan geçerli genellemeler yapılabilmesini engeller ama burada amaç gerçek izleyicilerin toplumsal dünyalarının özgül yanlarına ilişkin bilgi edinmektir. Böylelikle bu araştırmalar gerçek insanların gündelik yaşamlarında televizyonla olan ilişkilerinin özgül ayrıntılarına yönelik duyarlılığın artmasına katkıda bulunurlar. Televizyon izleme deneyiminin anlaşılmasında bu duyarlığın yeri çok önemlidir. Çünkü televizyon gerçek insanlar tarafından, doğal ortamlarında ve gündelik ilişkileri içinde kullanılan, üstelik bu gündelik ilişkilerin hem bir parçası hem de bu ilişkilerin bir anlamda yapılaştırıcısıdır. Bu tür araştırmaların televizyon-izleyici ilişkisini, izleyicinin mahrem alanına, yani ailenin yuvasına taşıyarak, televizyonun içeriğinden, yani ekranlardaki dünyadan ziyade izleyicinin gündelik yaşamındaki etkinliklerine ağırlık verecek şekilde tanımladığı buraya kadar söylenenlerden açıkça ortaya çıkmaktadır. Etnografinin geniş kapsamı iki çok önemli çözümleme biçimini kolaylaştırmaktadır. İlkin medya çıktısının giderek artan metinlerarasılıklarını tespit etmeyi sağlamaktadır. İkinci olarak da etnografi giderek küreselleşen medya üretimini insanların gündelik yaşamlarında kullanması suretiyle nasıl farklılaştıklarını anlamaya yardımcı olmaktadır (Mutlu, 1999). Televizyon ve çocuk oyunlarının ilişkisini anlamaya çalışan bu çalışma medya etnografisinin bakış açısından beslenmekle birlikte araştırmaya dahil edilen çocuklarla görüşülmemesi, inceleme süresinin sınırlı olması gibi unsurlarla etnografik bir çalışma değildir. Sahanın Sesleri kitabında (2013) yer alan 'Gündüz Kuşağı Televizyonunun Etnografik Analizi: Bir İntrospektif Çalışması' başıılı çalışmada da işaret edildiği gibi izleyici araştırmalarının etnografik olarak tanımlanmasında bazı sorunlar söz konusudur. Debra Spitulnik'e göre (akt. Çaylı Rahte, 2013) "katılımcı gözlemin sınırlı olduğu, üzerine çalışma yapılan insanların gündelik pratiklerine ve sosyal dünyalarına aktif olarak dahil olunamayan araştırmalar tamamıyla etnografik araştırmalar sayılamayacak olsalar da, bu araştırmalar da üretici-tüketici ikileminin aşılmasını sağlayarak, medya içeriklerini tüketmenin aynı zamanda bir kültürel üretim biçim, olduğunu ortaya koymuşlardır".

Jean Pierre Rossie'nin (2001) Fas ve Tunus'ta yapmış olduğu çalışmasında da belirttiği gibi elbette televizyon geleneksel oyun oynama biçimini değiştirmiştir ancak oyun oynamanın kendisini ortadan kaldırmamıştır. Çalışmada Marsh ve Bis- 
hop'ın $(2014$, s. 17) televizyona karşı çocuk oyunlarının bir direnci olduğu düşüncesinden yola çıkarak, oyunların televizyon dolayımıyla melezleştiği savunulmaktadır. Bu sav doğrultusunda, çocuk oyunları ve televizyon ilişkisi nedir, çocuk oyunlarında televizyon anlatılarından iz var mıdır gibi sorulara cevap aranmaktadır. Araştırma 2015-2016 eğitim öğretim yılı bahar döneminde beș ay boyunca Sivas merkezde bulunan dokuz devlet anaokulunda ${ }^{5}$ yürütülmüştür. Televizyon ve oyun kültürü ilişkisinin en iyi incelenebileceği, çocukların toplu bir şekilde belli bir zaman aralığında bir arada oyun oynadıkları mekân olması açısından da anaokulları tercih edilmiştir.

Çalışmanın evreni Piaget'in (2004) işlem öncesi çocuklar olarak tanımladığı iki ile yedi yaşları arasında yer alan çocuklardır. Bu dönem büyük ölçüde bir önceki dönemde başlayan tasarımlama işlevinin gelişmesini içermektedir. Sembolik işlevlerin ve bu işlevlerin etkili bir biçimi olan dilin kazanılması bu dönemin ürünüdür. Televizyon programlarının bu yaştaki çocuk izleyiciyi hedeflediği düşünüldüğünde çocukların bu dönemdeki öğrenme mekanizmalarının tam olarak bilinmesinde fayda vardır. Bu dönem çocuğu çevresindeki bireylerle aktif bir iletişimde bulunabilir. Ancak bu iletişim biçimlerini tanımlayan temel kavram benmerkezciliktir. Kendi üzerine yoğunlaşmış olan çocuğun algıları kendi üzerinde yoğundur. Öznel olanla nesnel olanı ayıramazlar, bunun sonucu olarak da doğal olayların insanlar tarafından kontrol edildiklerine inanırlar. Bu evredeki çocukların büyük bir bölümü ayrıntıları dikkate almadan genel olarak alırlar ve ilişkisiz objeler ve fikirler arasında bağlantı kurarlar (syncretism). Çocuk her şey arasında her türlü ilişki kurabilir. Yine bu dönemde çocuk parçayla bütünü aynı zamanda düşünememekte, parçalar halinde algılamaktadır. Oyun ve taklit çocuğun öğrenmesinin temel dayanaklarıdır. Taklit, hazır bir eylem biçiminin çocuğun davranışına eklenen pasif bir süreç değil, aktif bir biçimde uymayı içeren bir süreçtir. Oyun ise, özümleme yoluyla gerçekleşen bir çeşit uyum olarak tanımlanmaktadır. Taklit ve oyun çocuğun çevreye uyum sağlamasının bir sonucudur (Timisi, 2011, s. 12). Araştırmanın çalışma grubunu Piaget'nin tanımladığı bu dönemin beş yaş grubu sınıflarda öğrenim görmekte olan toplam 351 öğrenci oluşturmaktadır. Çocuklardan 163'ü kız $188^{\prime} i$ ise erkektir. Bu yaş grubu çocukların ele alınmasında çocukların paralel oyun ${ }^{6}$ dönemini bitirmiş olmaları göz önünde tutulmuştur. Çalışma, öğrencilerin müfredatında yer alan serbest zaman aralığında oynadıkları oyunlarla sınıllandııımıştır. Araştırmanın yapıldığı okulların devlet okulu olması nedeniyle öğrenim yarım gündür. Bu nedenle araştırmanın yapıldığı dokuz okulun hem sabahçı (7.30-9.00), hem de öğleci (12.30-14.00) grupları çalışmaya dâhil edilmiştir.

Televizyon dolayımıyla oyunların melezleşmesinin anlaşılabilmesi için veri toplama tekniği olarak etnografik araştırma yöntemlerinden gözlem kullanılmıştır. Arthur Asa Berger'in (2000: 161) İletişim Araştırmaları kitabında belirttiği gibi gözlem, araştırmacıya gerçek yaşamın anlaşılmasını ve üzerine çalışımasına olanak sağlamaktadır. Gözlemin belirgin özelliği, alana çıkmak ve başka insanların gündelik tecrübe ve faalivetlerine vakın olmaktır. Yakın olmak kavramı ise, insanların yaşamlarını ve yapıp

5 Aksu Anaokulu, Bahattin Makbule Özberk Anaokulu, Halide Edip Adıvar Anaokulu, Melek Reşit Hanım Anaokulu, Melike Turan Anaokulu, Kılavuz Anaokulu, Mimar Sinan Anaokulu, Nene Hatun Anaokulu, Zübeyde Hanım Anaokulu.

6 Oyuncakla oynanıp başkaları ile oynamaya girişmemek. 
ettiklerini içeren gündelik tekrarlarla fiziksel ve sosyal açıdan yakın olmayı gerektirmektedir. Gözlem tekniği belli bir amaç doğrultusunda araştırılmak istenen olguya dair izleyerek ve dinleyerek bilgi edinmektir. Gözlem, belirlenmiş kategorilerden ziyade, bireylerin deneyimlediği yaşamı yakalamaya ve anlamaya çalışır. Bu tekniğe göre birey davranışları belli bir amacı içerir, değer ve inançlar bu davranışlarla yansıtııır. Çoğunlukla, davranışları yaşanan zamanda yakalamak için bireyler doğal ortamlarında gözlemlenir. Niteliksel gözlem, genel yasalar ortaya koyan nomotetik yaklaşımda ziyade her olayı ayrı ayrı inceleyen idiyografik yaklaşımı kullanır. İnsanların davranışlarıı gözlemlenerek, insanların ne söylediği, hangi kelimeyi kullandıklarını, hangi açıklamaları yaptıklarını, inançlarının ne olduğunu anlamak mümkün olmaktadır. Aynı zamanda, topluluk için bireylerin birbirleriyle ilişkileri, bireylerin grupla olan ilişkileri, topluluğun birbirleriyle ilişkileri de açıklanabilmektedir. Gözlem ile sıradan, gündelik detaylar, önemsiz görünenler birer veri olarak kabul edilir. Bu sayede davranışların kapsamlı eğilimleri tespit edilmektedir (McKechnie, 2008, s. 573-574). Araştırmada kullanılan gözlem sayesinde çocukların oyun pratiklerine dair gözden kaçan ya da dikkat edilmeyen detaylar incelenmiş̧ir. Bu detay sayesinde ise çocuk oyunlarının pek çoğunda televizyon anlatılarından unsurlar yakalanmaya çalışılmıştır.

Çocuklar, Milli Eğitim Bakanlığı müfredatında bulunan 'serbest oyun' saati sırasında kendi sınıflarında gözlemlenmiştir. Junker'ın gözlem (aktaran Neuman, 2008) için tanımladığı dört rolden, katılımcı olarak gözlemci rolü tercih edilmiştir. Çocukların dikkatlerini dağıtmamak, kendi ortamlarında onları rahatsı etmemek için bu rol tercih edilmiştir. Milli Eğitim Bakanlığı tarafından anaokullarında ses ve görüntü kaydı yasak olduğu için gözlemler sırasında ses, fotoğraf veya video kaydı yapılmamışır. Gözlem sırasında yol göstermesi için şu sorular hazırlanmıştır:

\section{Çizelge 1: Gözlem için yol gösterici sorular}

\begin{tabular}{|l|l|}
\hline & - Oyunun bir adı var mı? \\
& - Oyunun türü nedir? \\
& - Oyun hangi kurallarla oynanıyor? \\
Gözlem için yol & Oyunun somut araçları var mıdır? \\
gösterici soru formu & Oyun iki cinsin de oyunu mu? \\
& Oyunun oynanması için sınıf içinde bir mekan \\
& veya araca gerek var mı? \\
& - Oyunda tekerleme, şarkı ya da başka konuşma \\
& biçimleri var mı? \\
& Çocukların oyunlardaki rol tercihleri nelerdir? \\
\hline
\end{tabular}

Çocukların ev içindeki televizyon izleme pratiklerinin neler olduğunun ortaya konması ve gözlem verilerinin tutarlığının sınanması için çocukların aileleri ile

7 Dört tür gözlemci rolü bulunmaktadır: 1) Tamamen gözlemci: Araştırmacı tek yönlü bir aynanın arkasındadır ya da kulak misafiri olan bir kapıcı gibi 'görünmez bir rolü' vardır. 2) Katılımcı olarak gözlemci: Araştırmacı baştan itibaren bilinir ancak kısıtlı temasta bulunur. 3) Gözlemci olarak katıIımcı: Araştırmacı açıktır ve katılımcıların yakın bir arkadaşıdır. 4) Tamamen katıııcı: Araştırmacı bir üye gibi davranır ve içeridekilerin gizli bilgilerini paylaşır (Neuman, 2008, s. 554). 
yüz yüze görüşmeler yapılmıştır. Bu sayede çocukların televizyon ilişkisine dair veriler elde edilmiş bu veriler gözlem sonuçlarıyla da ilişkilendirilmeye çalışılmıştır. Görüşme yapılanlardan 221 'i anne ve babalar olurken, 130 'u aileyle yaşayan ailenin diğer fertleridir (dede, anneanne, babaanne, teyze, amca, hala, dayı vb.). Görüşme yapılan aile fertlerinin yaş aralıkları 21 ve 72 yaş aralığındadır. Görüşme sırasında sorulan sorular şu şekildedir:

Çizelge 2: Görüşmede sorulan sorular

\begin{tabular}{|c|c|}
\hline Görüşme soruları & $\begin{array}{l}\text { - Çocuklar hangi kanalları izliyor? } \\
\text { - Çocuklar hangi çizgi film kanallarını } \\
\text { izliyorlar? } \\
\text { - Günün hangi zaman aralığında televizyon } \\
\text { izliyorlar? } \\
\text { - Günde kaç saat televizyon izliyorlar? } \\
\text { - İzlenen programı kim belirlemektedir? } \\
\text { - Hangi çizgi filmleri izliyorlar? }\end{array}$ \\
\hline
\end{tabular}

\section{Bulgu ve Tartışma}

Çocukların televizyon izleme pratiklerine dair velilerle yapılan görüşmelerden elde edilen sonuçlarının ortaya konması oyunların dönüşüm pratiklerinin anlaşılmasını da kolaylaştıracaktır.

\section{Ailelerle Yapılan Görüşmeler}

'Çocuklar televizyon izliyor mu' sorusuna ele alınan çalışma grubundaki 351 velinin tamamı evet yanıııı vermiştir. Tüm çocukların televizyon izlediğinin ortaya konmasından sonra bu pratiğin anlaşılabilmesi için daha detaylı sorular sorulmuştur. Sorulardan ilki çocukların hangi kanalları izlediğine dair olmuştur. Aşağıdaki çizelge çocukların izlediği kanalları göstermektedir.

Çizelge 3: Çocukların izlediği kanallar

\begin{tabular}{|c|l|}
\hline & - TRT Çocuk \\
& - Cartoon Network \\
& - Minika Çocuk \\
& - Minika Go \\
& - Disney Channel \\
& - Disney Junior \\
& - Planet Çocuk \\
\hline
\end{tabular}




\begin{tabular}{|c|l|}
\hline & $\bullet T R T 1$ \\
& \\
& $\bullet$ Kanal D \\
& $\bullet T V 8$ \\
& $\bullet$ Star TV \\
& $\bullet$ Show TV \\
& $\bullet$ NTV Spor \\
\hline
\end{tabular}

Ailelerle yapılan görüşmelerde çocukların ortalama televizyon izleme saatleri 4-5 saattir, bunun bir-bir buçuk saati sabah uyandıktan hemen sonra geriye kalanı ise okuldan geldikten sonra ve aile bireyleriyle izlenilen akşam saatleridir. İzlenen programı kim belirlemektedir sorusuna ailelerin pek çoğu gün içinde çocuğun kendisinin kanal ve program tercih ettiğini belirtmiştir. Akşam saatlerinde ise kanal ve programı belirleyenin ise çoğunlukla ebeveynler olduğu saptanmıştır. Akşam saatlerinde çocukların televizyon izleme pratikleri tek başına yapılan bir eylemden çok aile ile yapılan bir eylem olduğu için ailenin televizyon izleme pratiği çocuğa da sirayet etmektedir (Lemish, 2007, s. 22). Yanıtlar sırasında anlaşılmıştır ki çocuklar sadece tematik çocuk kanallarını izlememektedir. Aileleri ile birlikte genel izleyici kitlesine yönelik olan kanalları izlemekte hatta bazı programları takip etmektedirler.

Çizelge 4: Aile ile birlikte izlenen programlar

\begin{tabular}{|l|c|c|c|c|c|c|}
\hline & $\begin{array}{l}\text { Diriliş̧ } \\
\text { Ertuğrul }\end{array}$ & $\begin{array}{l}\text { Kurtlar } \\
\text { Vadisi }\end{array}$ & $\begin{array}{l}\text { Muhteşem } \\
\text { Yüzyıl }\end{array}$ & $\begin{array}{l}\text { Arka } \\
\text { Sokaklar }\end{array}$ & Survivor & $\begin{array}{l}\text { O Ses } \\
\text { Türkiye }\end{array}$ \\
\hline Kız & - & - & $\sqrt{ }$ & $\sqrt{ }$ & $\sqrt{ }$ & $\sqrt{ }$ \\
\hline Erkek & $\sqrt{ }$ & $\sqrt{ }$ & $\sqrt{ }$ & $\sqrt{ }$ & $\sqrt{ }$ & $\sqrt{ }$ \\
\hline
\end{tabular}

Çizelge 4'te belirtildiği üzere tüm ailenin bir arada olduğu anlarda en çok izlenen program türünün dizi olduğu anlaşılmıştır. Dizilerden sonra ikinci sırada izlenenler yarışma programlarıdır, son sırada ise haberler ve spor programları vardır. Ancak haberler, dizi saati beklenirken daha çok baba istediği için izlenmektedir. Bir arada geçen zamanların en çok izlenen program türü olan diziler, yarışma programları aile içi iletişimde de özdeşim kurma ve benzetme yolu ile etkinliğini tüm yollarla hissettirmekte ve çocuğun oyunlarına yansımaktadır. Çocuklar aileleri ile birlikte bulundukları ortamda oyun oynarken arka plan televizyondan ${ }^{8}$ etkilenmektedirler. Arka plan televizyon çocukların oyuncaklarla oynamalarını bozmakta, oyun oynama sürelerini kısaltmakta, oyun oranını azaltmaktadır. Schmidt ve arkadaşlarının da (2008, s. 1147) belirttiği gibi özellikle okul öncesi çocukların arka plan televizyona bir anlığına bakmaları oyun dikkatini dağıtmakta ve hatta bitirmektedir. Televizyona bakmayı bırakan çocuk ne oynadığını ya da oyun düzenini unutmakta bu nedenle yeni bir oyuna geçmektedir. Bu durum ise oyun sürelerinin ve bölümlerinin de kısalmasına neden olmaktadır.

8 Çoğunlukla çocuklar tek başlarına oynarken veya aileleri varken oynadıkları sırada açık olan televizyonun bulunmasına arka plan televizyon denmektedir (Kirkorian, 2009, s. 1350). 
Çocuklar hangi çizgi filmleri izler sorusuna görüşme yapılan tüm aileler hemen hemen aynı filmlerin isimlerini vermişlerdir. Buna göre izlenen yirmi dokuz çizgi filmin on ikisi çocukların ortak tercihidir. Ortak olan bu filmlerin dışında sadece kızların izlediği filmlerin sayısı yedidir. Erkekler de ise bu rakam ona ulaşmaktadır.

Çizelge 5: Çocukların İzlediği Çizgi Filmler:

\begin{tabular}{|c|c|c|}
\hline Film isimleri & KIz & Erkek \\
\hline Pepee & $\sqrt{ }$ & $\sqrt{ }$ \\
\hline Marsu pilami & $\sqrt{ }$ & $\sqrt{ }$ \\
\hline Keloğlan & $\sqrt{ }$ & $\sqrt{ }$ \\
\hline Arı Maya & $\sqrt{ }$ & $\sqrt{ }$ \\
\hline Canım Kardeşim & $\sqrt{ }$ & - \\
\hline Niloya & $\sqrt{ }$ & - \\
\hline Çilek Kız & $\sqrt{ }$ & - \\
\hline Karlar Ülkesi & $\sqrt{ }$ & - \\
\hline Ormanın Kitabı & $\sqrt{ }$ & $\sqrt{ }$ \\
\hline Deniz Kızı & $\sqrt{ }$ & - \\
\hline Rafadan Tayfa & $\sqrt{ }$ & $\sqrt{ }$ \\
\hline Wings Club & $\sqrt{ }$ & - \\
\hline Prenses Sofia & $\sqrt{ }$ & - \\
\hline Şimşek McQueen & - & $\sqrt{ }$ \\
\hline Transformers Prime & - & $\sqrt{ }$ \\
\hline Gumball & - & $\sqrt{ }$ \\
\hline Ben 10 & - & $\sqrt{ }$ \\
\hline İtfayeci Sam & $\sqrt{ }$ & $\sqrt{ }$ \\
\hline Transformers & - & $\sqrt{ }$ \\
\hline Tom ve Jerry & $\sqrt{ }$ & $\sqrt{ }$ \\
\hline Scoobe Doo & $\sqrt{ }$ & $\sqrt{ }$ \\
\hline Beyblade & - & $\sqrt{ }$ \\
\hline Örümcek Adam & $\sqrt{ }$ & $\sqrt{ }$ \\
\hline Süper Köpek Kripto & $\sqrt{ }$ & $\sqrt{ }$ \\
\hline Zack ile Vak Vak & $\sqrt{ }$ & $\sqrt{ }$ \\
\hline GGO Futbol & - & $\sqrt{ }$ \\
\hline Batman & - & $\sqrt{ }$ \\
\hline Ninja Go & - & $\sqrt{ }$ \\
\hline Ten Kai Şovalyeleri & - & $\sqrt{ }$ \\
\hline
\end{tabular}

Pek çok çalışma cinsiyet rollerinin öğrenilmesinin ilk basamağı olarak aile gibi birincil toplumsallaşma etmenlerini görürken kitle iletişim araçlarının giderek bu alanda daha fazla önem kazandığı da kabul edilmektedir. Televizyon belirli cinsiyet modellerini çocuğa örnek modeller aracılığıyla aktarırken ve toplumda yerleşik olan geleneksel rol beklentilerini güçlendirerek ya da bu beklentilerin değişmesine aracılık ederek işlevsel olmaktadır. Özellikle belirli bir rol modelin 
davranışları hakkında çok az biliş olan bu süreçte çocuklar etkiye çok açıktırlar. Çocukların özellikle televizyon aracılığıyla yakın çevre dışındaki dünyanın değerlerini öğrenebildiklerini, cinsiyet rollerinin de televizyonda evrensel değerler olarak sunulduğunu söylemek yanlış olmayacaktır. Toplumsal cinsiyet rolleri tasarımları büyümekte olan kız ve erkek çocuklarının kimlik inşalarında, bireyselleşmelerinde, değerlerinin oluşumunda ve hayatlarına ilişkin kararlarında belirleyici olmaktadır. Kapitalist/ataerkil toplumlarda kadınlar erkeklere göre ve onun negatif yansıması olarak değerlendirilmektedir. Statüsü yüksek, ayrıcalıklı ve öncelikli olan erkek ve onun temsil ettiği değerlerdir. Örneğin hırçınlık, rekabetçi olma, bağımsızlık, kendine güven, akıl ve karar verebilme erkek özellikleri, bunun tersi yumuşak olmak, nezaket, başkalarını dikkate alma, uzlaşıdan yana olma, duygudaşlık, konuşkanlık gibi sıralanabilecek özellikler kadınsı olarak tanımlanmaktadır. Kadın özel alanda, erkek ise kamusal alanda tanımlanmaktadır. Bakma, yetiştirme, insan yaşamının yeniden üretimi kadınların, koruma, kollama, ekonomik değer üretme ve toplumsal sistemi yeniden üretme erkek alanıdır. Elbette tarihsel süreç içinde roller açısından bir farklılaşma söz konusu olsa da tek tek bireylerin gündelik yaşam pratiklerinden ziyade ataerkil/kapitalist sistemin yeniden üretimi bu farklıık üzerinde kuruludur (Timisi, 2011).

Çalışmanın yapıldığı dönemde çocukların izlediklerini söyledikleri çizgi filmlere bakıldığında program türleriyle toplumsal cinsiyet arasındaki ilişki, televizyonun stratejisinin anlaşımasına da neden olmaktadır. Çocuk programları da kız ve erkek çocuklar dikkate alınarak tasarımlanmaktadır. Örneğin Spiderman, Batman, Tenkai Şövalyeleri, Ninja Go gibi çizgi filmler erkek çocuklar için tasarlanmaktadır. Televizyonun tarihi içinde en çok bilinen kahramanlar erkektir ve erkek çocuklara yönelik çizgi ve diğer filmler kızlara yönelik olanlardan sayıca fazladır. Kızlar için ise temel olarak Barbie oyuncağını, sihirli prensesleri merkeze alan filmler ve karakterler üretilmektedir.

Görüşmelerden çıkan bir başka dikkat çekici sonuç ise çocukların kendileri için üretilen sınırlı sayıda da olsa çocuk dramalarını takip ettikleridir.

Çizelge 6: İzlenen Çocuk Dramaları

\begin{tabular}{|l|l|}
\hline Program Adı & Kanal Adı \\
\hline Sihirli Annem & Kanal D \\
\hline Eyvah Dedem Büyüdü & Minika Cocuk \\
\hline Süper Matrak & Disney Channel \\
\hline Dino Dan & Minika Çocuk \\
\hline
\end{tabular}

\section{Melezleșen Oyunlar}

Çocuk etkinliklerinin varlığını ve gelişimini çocukların içinde yaşadığı toplum belirler. Tüketim piyasaları, şirketler, reklamlar, hızlı teknolojik gelişmeler ve kitle iletişim araçlarının yoğun enformasyon bombardımanı içinde yaşayan çocuk bu toplumdan bağımsız 
bir oyun kültürü geliştiremez. Buradan hareketle çocukların oyunlarının anlam ve yapısının farklılaşmasının izleri oyunları gözlemleyerek sürülmüştür. Çocukların birbirleriyle eğlenmek için girdiği bir etkinlik olarak oyunlar Artin Göncü'nün (2001, s. 45) kategorileştirmesiyle kodlanmıştır. Göncü'ye göre beş tür oyun kategorisi vardır. Bu kategoriye masa üstü/ okul araç gereçleriyle yun ve sök tak/inşa oyunları da eklenmiştir. Çizelge 7, bu kategoriler sayesinde televizyonun etkileriyle ortaya çıkan melez oyunları göstermektedir.

\section{Çizelge 6: Çocukların Oynadıkları Oyun Türleri}

\begin{tabular}{|c|c|}
\hline $\begin{array}{l}\text {-Mış Gibi yapma/ İmge } \\
\text { Oyunu }\end{array}$ & $\begin{array}{ll}\text { - } & \text { Turabi olmak } \\
\text { - } & \text { Hürremcilik } \\
\text { - } & \text { Pepeecilik } \\
\text { - } & \text { Restorantçılık } \\
\text { - } & \text { Annecilik-Babacıllık } \\
\text { - } & \text { Askercilik } \\
\text { - } & \text { Srensesçilik } \\
\text { - } & \text { Polisççilik } \\
\text { - } & \text { Atçılık } \\
\text { - } & \text { Polatçılık } \\
\text { - } & \text { O Ses Türkiye }\end{array}$ \\
\hline Obje Oyunu & $\begin{array}{ll}\text { - } & \text { Top atmaca-golcülük oynama } \\
\text { - } & \text { Şimşek McQueen arabalarla yarışma } \\
\text { - } & \text { Minderlerle güreş yapma } \\
\text { - } & \text { Kilıç oynama } \\
\text { - } & \text { Beyblade ile maç yapma } \\
\text { - } & \text { Arabalorlarla oynama } \\
\text { - } & \text { Plastik meyve-sebzelerle oynama } \\
\text { - } & \text { Örüla oynama } \\
& \text { Öumcek Adam figürleri ile oynama }\end{array}$ \\
\hline Dil Oyunu & $\begin{array}{ll} & \text { Ankara havası ile dans etme } \\
\text { - } & \text { Pepee şarkıları ile rol yapma } \\
\text { - } & \text { Şimşek McQueen replikleri ile araba yarışı yapma } \\
\text { - } \quad \text { Yıldız şarkıcılık }\end{array}$ \\
\hline Fiziksel/Bedensel Oyun & $\begin{array}{ll}\text { - } & \text { Vurmaca (Ten Kai Savaçıları gibi) } \\
\text { - } & \text { Yakalama (Örümcek Adam gibi) } \\
\text { - } \quad & \text { Itme, Isırma ve Düşürme (Zombiler gibi) } \\
\end{array}$ \\
\hline Kurallı Oyun & $\begin{array}{ll}\text { - } & \text { El sende } \\
\text { - } & \text { Kutu kutu pense } \\
\text { - } & \text { Yağ satarım } \\
\text { - } & \text { Yerden yüksek }\end{array}$ \\
\hline $\begin{array}{l}\text { Masaüstü/Okul Araç- } \\
\text { gereçleri ile Oyun }\end{array}$ & $\begin{array}{ll}\text { - } & \text { Hamurla oynamak } \\
\text { - } & \text { Makasla kağıt kesmek } \\
\text { - } & \text { Boya yapmak } \\
\text { - } & \text { Resim yapmak }\end{array}$ \\
\hline Sök-Tak/ Inşa Oyunları & $\begin{array}{l}\text { - } \quad \text { Ahşap/plastik bloklarla kule inşa etmek } \\
\text { - } \quad \text { Pepee küpleri ile ev inşa etmek }\end{array}$ \\
\hline
\end{tabular}


Yukarıdaki çizelgeden de anlaşılacağı üzere çocuklar filmlerde gördükleri düşsel oyunları, gerçek oyunlara ustalıkla çevirebilmektedirler. Sıralanmış yedi oyun kategorisinden beşinde televizyon anlatılarının oyunlara etki ettiği gözlemlenmiştir. Kalan kurallı oyun ve okul araç gereçleriyle oyun kategorileri geleneksel formlarıyla çocukların oyunlarında devam etmektedir. -Mış gibi yapma, obje, dil, bedensel ve sök tak oyun kategorilerinde televizyon anlatıları oyunların melezleşmesine neden olduğu saptanmıştır.

\section{-Mış Gibi Yapma/İmge Oyunu}

Etkinliğe katılan kişilerin, bir fikri veya bir objeyi başka bir şeyin anlamını temsil etmek ve eğlenmek amacıyla kullandıkları oyundur. Örneğin, doktorculuk oynamak, evcilik oynamak gibi sembolik etkinlikleri içerir. Bu tür oyunlar çocukların, anne-babayla olan yaşamlarını, okudukları kitapları, birlikte izledikleri programları yansıtmaktan daha fazlasıdır. Çocukların -mış gibi oyunlarında medyanın rolü önemlidir. Çocuklar yaratıcı ve fantezi oyunlarına medya metinlerinin bilgi ve dilini dâhil etmektedir (Göncü, 2001, s. 45; Marsh ve Bishop, 2014, s. 19-20).

-Mış gibi oyunlarda Opiesler (aktaran Marsh ve Bishop, 2014, s. 43) sekiz kategori oluşturmuş: Anneler ve babalar, okulda oyun, araba kazası (erkekler kaza yapar, kızlar hemşire olur), atçılık, hikaye kitabının dünyası (çocuklar anormal durumları çözebileceklerine inanırlar), savaş oyunları, hırsız ve polis oyunları, cadı ve peri oyunları (çoğunlukla kızların oynamayı tercih ettiği oyunlardır. lyi ve kötülerin savaştığı bir dünyadır). Opies'lerin sıraladığı bu kategorilerden; arabacııık, atçılık, savaş oyunları, hırsız-polis oyunu, cadı-peri oyunu bu çalışmada da gözlemlenmiştir. Bunun yanında yapılan gözlemlerde çocukların televizyon anlatılarından etkilenerek oynadıkları oyunlar şu şekilde sıralanmaktadır: Turabi olmak, Hürremcilik, Pepeecilik, Restorantçıı, annecilik-babaclık, askercilik, prensesçilik, polisçilik, Polat Alemdarcilık.

Çizelge 6'dan da anlaşılacağı üzere çocuklar filmlerde gördükleri düşsel oyunları, gerçek oyunlara ustalıkla çevirebilmektedirler. Her birinde olağanüstü bir yaratıcı oyunculuk olduğundan istedikleri karakterin rolüne istedikleri anda geçebilmektedirler. Araştırmalar göstermektedir ki, çocuk oyunları televizyon yıldızlarından etkilenirler özellikle de yetenek yarışmalarında yıldızlaşan insanlardan. Çocukların bu durumları yıldız (star) bağımlılığı olarak da tanımlanmaktadır (Marsh ve Bishop, 2014, s. 139). Bunun dışında dönemsel olarak eğer etkisi altında kaldıkları birden fazla film varsa bu karakterleri de sırayla ve dönüşümsel olarak canlandırabilmektedirler. Survivor ve O Ses isimli yarışmaları çocuklar kendi düş dünyalarıyla yeniden üretmişlerdir. Sınıfta bulunan beş öğrenciden (kız-erkek karışık) ikisi (lider yapılı) ünlüler takımını temsil ederken üçü gönüllüler takımını temsil etmiştir. Bir öğrenci de eline ahşap blok oyuncaklardan birini alarak mikrofon yapmış ve Acun llıcalı olmuştur. Sınıfın diğer öğrencileri ise çocukların bu oyununa ünlüler ya da gönüllüler bağıııslarıyla katılmışlardır. Yarışmanın orijinalinde aslında gönüllüler takımında olan Turabi isimli karakter, çocukların oyununda ünlülerin takımında yer almaktadır. Tüm çocuklar için bu karakter çok değerlidir. Tüm çocuklar Turabi 
olmak ister. Aralarında bir eleme yaparak bu değerli karaktere bürünecek çocuk seçilir. Kimi zaman kızlardan biri Turabi olur. Bu karakterin davranışlarını kendi düş dünyalarına göre oynadıkları oyuna aktarırlar.

Araştırma sırasında O Ses Türkiye yarışmasının kurgulanarak oynandığı gözlemlenmiştir. Yarışmanın kurallarını eksiksiz anlatan sunucu, bu çocuğu dinleyip değerlendiren jüri üyeleri ve bu süreci izleyen, tezahürat eden izleyiciler vardır. Çocuklar özellikle jüri olmak için birbirlerini ikna etmeye çalışmışlar ancak başarılı olamamışlardır. Bunun üzerine programın orijinalinden farklı olarak her çocuk hem jüri hem yarışmacı olmuştur. Bu açıdan çocuğun, oyuna yalnızca büyüklerinden gördüğünü aktarmakla kalmadığını, kendi algıladıklarıyla, deneyimlerini de katarak sentezler yaptığını söylemek mümkündür. Bu tür yarışma programlarını yeniden yaratan çocukların esasen dil gelişimlerine katkısı olduğunu belirten Elizabeth Grugeon'a (2004, s. 85) göre, çocuklar aynı zamanda rekabet etmeyi, başarı için alternatif yollar bularak başarıya ulaşmayı öğrenmektedirler. Bunlar ise postmodern dünyanın postmodern çocuğunun sahip olması istenen yetileridir.

1950'li- 60'lı yıllarda sınırlı kanal ve sınırlı sayıda program nedeniyle tüm çocukların, programlardan haberdar oldukları için oyun kurmaları kolay olmuştur. Bu durumu 2000'li yıllar için söylemenin zor olduğunu belirten Marsh ve Bishop'a göre (2014, s. 73) sonsuz sayıdaki kanal ve program nedeniyle, çocuklar, programlar hakkında aynı bilgiye sahip olmuyorlar onun yerine birbirlerine programları anlatarak oyun kuruyorlar. Yazarların bu savlarının bir kısmı çalışmada gözlemlenmiştir. Çocukların aileleriyle izledikleri dizileri hepsi bilmemektedir. İki anaokulunda çocukların Arka Sokaklar dizisini izlemeyen çocuklara dizinin öyküsünü anlattığı gözlemlenmiştir. İzledikleri programları birbirlerine anlattıktan bir süre sonra tüm çocuklar oyun kurmuştur. Oyunda sırayla herkes kötü olmuştur. Polis olan kahramanlar ise okul oyuncaklarını da kullanarak kötülerle mücadele etmiştir-

Çocukların televizyon karakterlerini neden ve nasıl değerlendirdiği ve anlamlandırdığı sorusuna iki cevap vardır: ilki televizyon karakteri taklit, idolleştirme ve kimliğin oluşturulmasında önemlidir. İincisi ise çocukların taklit etmelerinde televizyon karakteri rol model olmaktadır. Yetişkin ve çocuk tüm izleyiciler televizyon karakteri ile duygusal ilişki geliştirirler, onları düşünür, yaşamlarını önemser. Televizyon karakterlerinin çeşitli kimlik oluşturma formları vardır. İzleyiciler özellikle de genç olanlar kendilerini karakterle orada hissederler muhtemelen de aynı cins, etnik köken, yaş veya görünüştedirler. Küçük çocuklar kendileri gibi güçsüz olarak sunulan ikincil pozisyondakilerle veya küçükler ya da hayvan karakterlerle özdeşim kurarlar. Çoğunlukla çocuk izleyiciler televizyon karakteri ve onun yaşamındakilerle aynı şeyleri paylaşırlar. Bu durumun -mış gibi oyunlarda kendini gösterdiği saptanmıştır. Pepee gibi dişlerini fırçalayan, Ten Kai Şovalyelerinin kahramanlığına sahip olan veya Örümcek Adam gibi ağ atan çocuklar gözlemlenmiştir. Lemish'e göre, (2007, s. 57-58) televizyon karakterleri çocukların onurlarını, inançlarını, tutumlarını, dünya görüşlerini, davranışlarını yeniden doğrular. Çocuklar istekli bir özdeşimle televizyon karakteriymiş veya onun davranışlarına sahipmiş gibi olurlar. Televizyon 
karakterleriyle para-sosyal etkileşimde de belirtildiği gibi çocuklar karakterlerle özdeşim kurmaktadır ve bu özdeşimler cinsiyetle ilişkilidir. Erkek çocuklar daha çok erkek kahramanla özdeşim kurarken kızlar kadın karakterle özdeşim kurarlar.

Çocukların aileleriyle ile birlikte izledikleri programlardan etkilendiklerini kurdukları oyun pratiklerinden takip etmek mümkündür. Bu tür programlarda çocuklar Diriliş Ertuğrul, Arka Sokaklar, Kurtlar Vadisi, Muhteşem Yüzyıl savaşmayı, öldürmeyi, yakıp yıkmayı öğrenmektedir. Ekranların sanal kahramanları çocuklarca bir süre sonra ciddiye alınıp gerçek yaşamda oynanmaya başlanmaktadır. Bunun en iyi örneğini erkek çocukların kurduğu en yaygın oyun olan savaş oyunlarında gözlemlemek mümkündür. Bu oyunlarda güç gösterisi eğilimi, kazanma hırsı, yok etme politikası kendisini göstermektedir.

Kız çocukları arasında Disney'in prensesleri çok popülerdir. Bu kahramanlar çocukların oyunlarına da sirayet eder ve toplumsal cinsiyet stereotipleri ${ }^{9}$ kullanmalarını sağlar (Coyne, 2016, s. 1910). Kızların oyunlarının pek çoğunda sadece bu prenseslerin hikâyeleri ile aileleriyle izledikleri Hürrem Sultan dizisini kullandıkları gözlemlenmiştir.

Çocuklar için hayali karakterler, gerçek karakterler kadar çekici ve ilgi uyandırıcıdır. Hatta bu karakterlere Hürrem Sultan bağlıık işaret eden beyanlarda bulunurlar. Kız çocuklar Muhteşem Yüzyıl dizisinde bulunan haremdeki karakterlerle özdeşim kurarlar. Çocukların arasında lider ruhlu ve baskın karakterli olan çocuk Hürrem Sultan rolünü oynar. Sultan olma üstünlügünden ötürü övülme veya saygı görme isteğini, arkadaşlarına sürekli yüksek ses tonunda emirler (bana su getirin hemen, çok yoruldum sandalyemi hazırlayın vb.) yağdırarak belirtir. Kendisine iltifatlar edilmesini, övülmeyi ister. Çocukların oynadığı bu oyun ile Huizinga'nın (1995) belirttiği, bireysel ve kolektif yetişkinleşmenin çocuklarca farkında olmadan içselleştirildiğinin izlerini de görmek mümkündür.

\section{Obje Oyunu}

Çocukların objeleri kullanarak eğlendikleri oyundur. Top atma, oyuncakları savurma, sıkma gibi eylemlerdir. Çocuklar sınıfta bulunan objelerle oynamaktan keyif almaktadırlar. Oynadıkları oyunlar şu şekilde sıralanmaktadır: Top atmaca, Şimşek McQueen arabalarla yarışmak, tamir takımlarıyla oynamak, minderlerle güreşmek, kılıç oynamak, Beyblade ile maç yapmak, doktor aletleriyle oynamak, arabalarla oynamak, plastik meyve sebzelerle oynamak, kukla oynamak, örümcek adam figürleriyle oynamak. Çocukların oynadığı objelerin bir kısmı çizgi film anla-

9 Bu göz alıcı karakterler çoğunlukla pasiftirler ve hep bir erkek tarafından kurtarımayı beklerler. Birkaç Disney prensesleri ile ilgili yapılmış olan içerik analizleri göstermiştir ki, toplumsal cinsiyet rolleri ile ilgili güçlü mesajlar göndermektedirler. 1937-2009 arası Disney prenseslerini ele alan araştırmaya göre cinsiyet her seferinde karmaşık hale gelse de hala güçlü geleneksel toplumsal cinsiyet rolleri ve stereotipleri çocuklar için pek çok filmde kullanır: Örneğin, fiziksel zayıflık, şefkatli, anaç, yardımsever, ürkek, itaatkâr kadın vb. (Coyne ve vd., 2016, s. 1910). 
tılarının yan ürünleridir. Şimşek McQueen arabaları, Scooby Doo figürleri, Süper Köpek Kripto eşyaları, Ittfayeci Sam arabaları ve aksesuarları.

Futbol televizyonlarda büyük yer tutar. Aileleri ile birlikte bu spor etkinliklerini izleyen çocukların oyunları, futboldan doğrudan etkilenmektedir. Gözlemler sonucunda top oynayan çocukların bir veya birkaç gün önceki futbolla ilgili olaydan etkilendiği ve esinlendiği ortaya çıkmıştır. Örneğin, Galatasaray ile Gençlerbirliği'nin maçında Sneijder'ın gol atması, çocuğun gözünde futbolcuyu kahramanlaştırmıştır. Çocuklar futbolcunun ismini bağırarak sevinç gösterileriyle (goooool, ve Sneijder vurdu vb.) oyunlarına dahil etmişlerdir.

\section{Dil Oyunu}

Çocukların sözcükleri ve sesleri kullanarak ortaya koydukları oyunlardır. Örneğin, motor sesi gibi sesler çıkarmak, sözcük uydurmak, şarkı söylemek, kelimelerin yapısını değiştirmek. Oyunlar televizyondaki müzik klipleri veya programlarından etkilenmektedirler. Daha çok kız çocukların oyunlarında ortaya çıkan bu rutin son dönemde erkeklerde de gözlemlenmektedir. Marsh ve Bishop (2014, s. 74) bunun nedenini şarkı yetenek yarışmaları olarak görmektedir. Onlara göre, 2009'daki Yetenek Sensin Britanya yarışmasında Michael Jackson tarzı dansın bir yarışmacı tarafından yapılması sonrası tüm erkek çocukların Michael Jackson tarzı dansı oyunlarına dâhil etmesi buna bir örnektir.

Yazarların belirttiği kliplerde yapılan dansların, mimiklerin sanki müzik kliplerindeymişçesine yapılması çalışmada da gözlemlenen bir durumdur. Örneğin, çocuklar aşağıdaki popüler türkünün sözlerini söylerken, aynı zamanda birlikte dans etmektedir: "ip attım ucu kaldı da daraz da gücü kaldı, en sevdim eller aldı, içimde acı kaldı. Ankara'nın bağları da büklüm büklüm yolları, ne zaman sarhoş oldun da kaldıramıyon kolları". 2015 yııının popüler şarkılarından Mış Mış ${ }^{10}$ ve Bangır Bangır ${ }^{11 \prime}$ çocukların oyunlarına da yansımıştır. Çocuklar aşağıda sözleri bulunan şarkının sözleri ve dansları eşliğinde oyun kurmuşlardır. Çocukların birbirleriyle oynarken söyledikleri şarkının sözleri şu şekildedir:

Nedir bu haller hadi açıl yeter

Ne kaçak ne göçek, ne tuzak

E, aman of slalom, hep hep zigzag

Dost kalalım, iyi hoşta anlayamam endişelerini

Geceleri tek doz yutalım mı, boş elveda (...)

Sorun bende mi sendeymiş

Daha iyisine layıkmışım, hangi kitaptan ezber bu

Mış mış mış da muş muş muş

La la la la la (...)

102015 Haziran ayında Riff Cohen - Dans Mon Quartier cover'ı olan, Sibel Algan'ın Türkçe söz yazdığı şarkı Simge tarafından seslendirildi. Yayınlandıktan sonra üç ay içerisinde Youtube'da 55 milyon izlenme ile rekor kırdı (www.simgesagin.com.tr, 29.07.2017).

112015 Nisan ayında söz, beste ve seslendirmenin Gülşen'e ait olduğu şarkı yayınladığı günden itibaren dijital (Ttnet, iTunes vb) ve fiziki satış listelerinde birinci sırada yer almıştır (www.google. com.tr/amp/s/m.mynet.com/gulsen, 29.07.2017). 
Çocuklar yukarıdaki şarkı sözleriyle sınıf içinde turlar atmakta arada sırada klipteki dans figürlerini uygulamaktadır. Bu sırada ise kızlar 'kadınsı', erkekler ise 'maço' tavırlar takınmaktadır.

Oyunların kimilerinde tekerlemelerle de karşılaşılmışıı. Bunlardan sadece bir tanesi grup liderlerini seçmek için kullanılan özgün bir tekerlemedir ${ }^{12}$. Çoğunlukla oyunlardaki tekerleme ve seslenişlerin de televizyondan etkilendiği belirtilebilir. Çocuklar şu tür tekerlemeler ve seslenmeler kullanmaktadırlar:

"...Beyblade güzel oyun, beni yenmek kolay değil, çok çalıştım dostum..." Beyblade

"... Haydi Bismillah cengaverlerim..." Diriliş Ertuğrul

"...biri kazanır, beceriksizleri kahvaltı niyetine yerim, ben şimşeğim..." Şimşek McQueen

\section{Fiziksel/Bedensel Oyun}

Gıdıklama, güreş, aerobik, çocukları havaya fırlatma gibi beden ve fiziksel etkinlik içeren oyunlar fiziksel/bedensel oyun olarak tanımlanmaktadır. Çocukların geleneksel işbirliğine dayalı kurallı oyunları çok az tercih ettiği gözlemlenmiştir. Bunun yerine çocuklar itme, ısırma, düşürmeden oluşan savaşma, zombicilik gibi bedensel oyunları tercih etmektedirler.

Arleen Dodds ve arkadaşlarının $(1992$, s. 7) yaptığı çalışmada savaş oyunları üç türe ayrılmaktadır: Çizgi film anlatılarıyla oynanan oyunlar, dramatik olarak kurulan oyunlar ve savaş oyuncakları ile kurulan savaş oyunları. Bu sınıflama ve örneklere gözlemlerde rastlanmıştır. Çocukların birkaçı Örümcek Adam ve Batman olur. Bir kısmı ise ağaçları söken, dünyayı istila eden düşman olur. Birbirlerini ittirerek, kovalayarak iki çizgi film anlatıından melez bir oyun yaratırlar. Fiziksel etkinlik içeren geleneksel oyunlar televizyon anlatısı ile Ten Kai savaşçıları gibi vurmaca, örümcek adam gibi yakalama, zombiler gibi ısırma ve düşürme olarak melez bir yapıya bürünmüştür.

Erkek çocuklar için üretilen Transformers, Gumball, Örümcek Adam, Ninja Go, Ten Kai Şovalyeleri gibi programların örtük özelliği, güçlü kuvvetli kahramanlar ve onların etrafındaki fantastik karakterlerin öykülerinden oluşmasıdır. Aynı zamanda bu tür kahramanların kullandığı araç gereçlerin metallerle donatılmış zırhlı silahlar olduğu da dikkat çekmektedir. Bunların öne çıkardığı tema güçtür. Çocukların oyunlarına bakıldığında da 'güç'lü olmak liderlikle eş tutulmaktadır. Çocuk güçlü olduğunu filmlerdeki kahramanlar gibi 'savaşarak' (birbirini ittirerek, bağırarak vb.) kanıtlama çabasındadır. Bedensel oyunun oynandığı bu oyunların çoğunlukla sonu yaralanma ve berelenmelerle bitmektedir.

12 "...Tıp tıp yağmur yağdı, çok üşüdüm, ıslandım, ben seni seçtim, kazandım..." 


\section{Sök-Tak/İnşa Oyunu}

Alet, araç ve parçaları söküp birleştirerek çocuğun ince motor becerilerini geliştiren oyunlardır. Sınıflarda bulunan ahşap/plastik bloklarla kule inşa etmek, Pepee küpleri ile ev inşa etmek çocukların oynadığı oyunlardandır. Çocuklar bu tür oyunlarda melez bir oyun kurmazlar ancak televizyon anlatılarının yan ürünlerinden de (Pepee blokları, Çilek Kız küpleri vb) kaçamazlar.

\section{Sonuç}

Çocuk oyunları evrensel bir etkinliktir. Ancak toplum yapısının uzantısı olarak farklııklar seyredebilir. Farklılığın yaşanmasında kitle iletişim araçlarının önemi göz ardı edilemeyecek kadar fazladır. Çalışmanın bulguları göstermektedir ki oyunlarda çocuklar yalnızca kendi doğal, maddi ve sosyo-kültürel çevrelerindeki değişime duyarlı olmakla kalmayıp, aynı zamanda da bu değişimlerin habercisidirler. Televizyon çocuklara tutum, davranış ve toplumsal yaşamla ilgili beklentileri yapılandırabilecek eşsiz çeşitlilik ve toplumsal modeller sunmaktadır. Sunduğu modeller ile çocuğun kendi ürettiği ve kendini ifade ettiği oyunlar melezleşmiştir. Çizgi film ve prime time dizilerin kahramanları, hikayeleri, müzik kliplerinin dansları ve müzikleri, izlenen futbol maçları çocukların oynadığı oyunlarda kendini göstermektedir. Çocuklar kimi zaman Hürrem Sultan, kimi zaman Polat Alemdar, Turabi, kimi zaman Wings Club kızları ya da Ben 10 takımından biri olarak oyun oynamaktadırlar.

Çalışma, pek çok geleneksel oyun formunun yeniden üretildiğini aynı zamanda medya dünyası ile yaratıcı, yeni oyunların ortaya çıktığını göstermiştir. Bu anlamda çalışma, antropoloji, halk bilim gibi farklı disiplinlerde çocuk oyunları ile ilgili araştırmalara da yeni tür oyunların ortaya çıkarılması ve saptanmasında da destek sağlayabilir. Çalışmanın gözlemleri, çocukların televizyon metinlerini yaratıcı bir şekilde yorumladığını göstermektedir. Bununla birlikte, çalışmanın, çocukların medya metinlerini nasıl alt üst ettiğine, kullandığına ve algıladığına dair saptamaları ile onların pasif alıcılar olmadıklarını da bir kez daha ortaya koymuştur. Çocukların televizyon karşısında pasif alıcı olmaktan ziyade anlatıları alımlayıp yaşamlarına ve tabii ki oyunlarına dâhil ettiklerini söylemek mümkündür.

Çalışmanın tespitleri, popüler kültür metinlerinden kaygı duyan eğitmen/ öğretmenlere ve ailelere çocuklar hakkında bilgi sağlamaktadır. Bununla birlikte araştırma, yirmi birinci yüzyılda eğitim için çoklu okuryazarlığın geliştirilmesinde ve ülkemiz çocuklarının, ailelerinin medya karşısındaki durumlarını iyileştirme, farkındalık düzeylerini artırma yolunda yapılan araştırmalarda kullanılabilir. Bu sayede de televizyon ve diğer elektronik medyayla çocuğun ilişkisi hem aile hem okul yaşamında yeniden düzenlenebilir. Medya yoğun dünyada çocukların eğitiminde medya okuryazarlığının da öneminin anlaşılması açısından çalışma bir yol gösterici olarak kullanılabilir. 


\section{Kaynakça}

Asa Berger, A., (2000). Media and Communication Research Methods An Introduction to Qualitative and Quantitative Approaches, London: Sage Publications.

Bağcı, M. T., (1999). Televizyon Illintili Çocuk Oyunları Üzerine Bir Araştırma, Cumhuriyet ve Çocuk: II. Ulusal Çocuk Kültürü Kongresi Bildirileri içinde, (133138), (B. Onur, Yay. Haz.). Ankara: Ankara Üniversitesi Çocuk Kültürü Araştırma ve Uygulama Merkezi Yayınları.

Coyne, S., Rasmussen, E. E., Linder, J. R., Nelson, D. A. ve Birkbeck, V. (2016). Pretty as a Princess: Longitudinal Effects of Engagement with Disney Princesses on Gender Streotypes, Body Esteem, and Prosocial Behavior in Children, Child Development, November/December, 87(6), 1909-1925.

Çaylı Rahte, E. (2013) Gündüz Kuşağı Televizyonunun Etnografik Analizi: Bir İntrospektif Çalışması, Sahanın Sesleri Illetişim Araştırmalarında Etnografik Yöntem içinde (17-50), (H. Ergül, Der.). İstanbul: İstanbul Bilgi Üniversitesi Yayınları.

Dodds, A., Dollins, R., Snyder, T. ve Welch, H. (1992). War and Peace: Toys, Teachers and Tots, 43rd Annual Conference of the Southern Association on Children Under Six Conference Papers içinde (2-28), Virginia: Department of Family and Child Development Virginia Polytechnic Institute and State University.

Elkind, D. (2011). Oyunun Gücü. (B. Onur, Yay. Haz., ve D. Erol Öngen, Çev.). Ankara: İmge Kitabevi Yayınları.

Elkind, F. (1995) Çocuk ve Toplum Çocuğun Toplumsallaşması. (N. Güngör, Çev). Ankara: Gündoğan Yayınları.

Göncü, A. (2001). Toplumsal ve Kültürel Bağlamın Çocuk Oyunlarındaki Yeri , 3. Ulusal Çocuk Kültürü Kongresi Dünyada Ve Türkiye'de Değişen Çocukluk içinde (37-50), (B. Onur, Yay. Haz.). Ankara: Ankara Üniversitesi Çocuk Kültürü Araştırma ve Uygulama Merkezi Yayınları.

Grugeon, E. (2004). From Pokemon to Potter: Trainee Teachers Explore Children's Media-Related Play, 2000-2003. J. Goldstein (Ed.), Toys, Games and Media içinde (73-89), Australia: Cambridge University Press, 1. Baskı: 1994.

Huizinga, J. (1995). Homo Ludens Oyunun Toplumsal İşlevi Üzerine Bir Deneme, (M. A. Kılıçbay, Çev). İstanbul: Ayrıntı Yayınları.

İnal, K. (2014) Çocuk ve Demokrasi, İstanbul: Ayrıntı Yayınları.

Kirkorian, H. L., Pempek, T. A., Murphy, L. A., Schmidt, M. E., ve Anderson, D. R. (2009). The Impact of Backround Television an Parent-Child Interaction, Child Development, September/October, 80 (5), 1350-1359.

Kline, S. (1993). Out of Garden Toys and Children's Culture in the Age of TV Marketing, NewYork: Verso Publication.

Lemish, D. (2007). Children and Television A Global Perspective, Malden: Bla- 
ckwell Publishing.

Lemish, D. ve Kolucki, B. (2013). Medya Ve Erken Dönem Çocukluk Gelişimi 'Çocuklarla İletişim: Yetiştirme, IIlham Verme, Harekete Geçirme, Eğitme ve İyileştirme İlke ve Uygulamaları', I. Türkiye Çocuk Ve Medya Kongresi Bildiriler Kitabı içinde (13-34), H. Yavuzer ve M. R. Şirin (Ed.), İstanbul: Çocuk Vakfı Yayınları.

Marsh, J. ve Bishop, J. C. (2014). Changing Play, Media and Commercial Culture from the 1950s to the Present Day, Berkshire: Open University Press.

McKechnie, L. E. F. (2008). Observational Research, The Sage Encyclopedia of Qualitative Research Methods, içinde (573-575), L. M.Given (Ed.), London: Sage Publications.

Mouritsen, F. (1998). Child Culture-Play Culture, Working Paper 2. Child and Youth Culture içinde (1-36), J. Guldber vd. (Ed.), Danimarka: Department of Contemporary Cultural Studies Odense University. Erişim 22 Nisan 2017, www. hum.sdu.dk/center/kultur/arb_pap/.

Mutlu, E. (1999) Televizyon ve Toplum, Ankara: TRT Eğitim Dairesi Başkanlığı.

Neuman, S. B. (1988) The Displacement Effect: Assessing the Relation Between Television Viewving and Reading Performence, International Literacy Association, Autum, 23 (4), 414-440.

Neuman, L. W. (2008). Toplumsal Araştırma Yöntemleri Nitel ve Nicel Yaklaşımlar, (S. Öze, Çev). Cilt: 2, 2. Baskı, İstanbul: Yayınodası.

Onur, B. (2005). Türkiye'de Çocukluğun Tarihi, Ankara: Imge Kitabevi Yayınları.

Onur, B. (2007) Çocuk, Tarih ve Toplum, Ankara: Imge Kitabevi Yayınları.

Özdoğan, B. (2000). Çocuk ve Oyun: Çocuğa Oyunla Yardım, 3. Baskı, Ankara: Anı Yayınları.

Piaget, J. (2013). Çocuğun Gözüyle Dünya, (i. Yerguz, Çev). 3.Baskı, Ankara: Dost Kitabevi Yayınları.

Piaget, J. (2004). Çocukta Zihinsel Gelişim, (H. Portakal, Çev). 2.Baskı, İstanbul: Cem Yayınları.

Postman, N. (1995). Çocukluğun Yok Oluşu, (K. İnal, Çev). Ankara: İmge Kitabevi Yayınları.

Rossie, J. P. (2001). Değişen Afrika Çocuklarında Değişen Oyuncaklar ve Oyun, (S. A. Cengiz, Çev.). Dünyada ve Türkiye'de Değişen Çocukluk, III. Ulusal Çocuk Kültürü Kongresi Bildirileri içinde (51-84). (B. Onur, Ed.). Ankara: Ankara Üniversitesi Çocuk Kültürü Araştırma ve Uyulama Merkezi Yayınları.

Schmidt, M. E., Pempek, T. A., Kirkorian, H. L., Lund, A. F ve Anderson, D. R. (2008). The Effects of Backround Television on the Toy Play Behaviour of Very Young Children, Child Development içinde (1137-1151). July/August, 79 (5). 
Sormaz, F. ve H. Yüksel (2012) Değişen Çocukluk Oyun ve Oyuncağın Endüstrileşmesi ve Tüketim Kültürü, Gaziantep Üniversitesi Sosyal Bilimler Dergisi içinde (985-1008), 11 (3).

Timisi, N. (2011). Elektronik Bakıcı: Televizyon Çocuk Ilişkisine Genel Bir Bakış, İstanbul: Derin Yayınları.

Yaşar, M. ve I. Paksoy (2011) Çizgi Filmlerdeki Saldırgan İçerikli Görüntülerin Çocukların Serbest Oyunları Sırasındaki Saldırganlık Düzeylerine Etkisi, Çukurova Üniversitesi Sosyal Bilimler Enstitüsü Dergisi içinde (279-298), 2 (20).

Yüzgüller, A. S. (2014). Çocuk Oyunları ve Bruegel'in Oyunu, Saraydan Sokağa Oyun içinde (137-149). (F. Akyürek ve G. Özturanlı, Ed.). İstanbul: Kabalcı Yayıncllik.

Sağın, S. İşte Ben Biografi. Erişim 29.07.2017, www.simgesagin.com.tr.

Gülşen'in Bangır Bangır Şarkısının Düşüşü. Erişim 29.07.2017. www.mynet. com/gulsenin-bangir-bangir-sarkisinin-dususu magazin-58303. 
